\title{
Gastric emptying of Caloreen meals in the newborn
}

\author{
C COSTALOS, G RUSSELl, Q AL RAHIM, I BLUMENTHAL, S HANLIN, AND I ROSS \\ Aberdeen Maternity Hospital, and Department of Chemical Pathology, University of Aberdeen
}

SUMMARY The gastric emptying of $10 \%$ solutions of glucose and of Caloreen, a glucose polymer, was compared in 16 newborn infants. Caloreen left the stomach more rapidly than glucose on all but one occasion. This has potential advantages to infant feeding.

In encouraging early feeding for low birthweight infants the paediatrician must take into account the problems that result from immature sucking and swallowing reflexes, an incomplete oesophageal cardiac sphincter, a poor gag reflex, and a small gastric capacity. ${ }^{1-2}$ Hypoglycaemia and jaundice may be prevented but only at the considerable risk of regurgitation and potentially fatal aspiration. ${ }^{3}$ Although there has long been agreement that early provision of an adequate caloric intake is desirable, ${ }^{4}$ the volume and composition of early feeds are still subjects for debate.

For some years it has been the practice in our special care nursery to provide light-for-dates and other infants at risk from hypoglycaemia with a high-energy diet for the first few days of life. Originally this was achieved by the introduction of glucosefortified feeds, ${ }^{5}$ but when these were given earlier and in larger volumes it became apparent that they often produced vomiting, abdominal distension, and diarrhoea. Caloreen* was substituted for glucose and it has been our impression that the incidence of these symptoms has decreased. This favourable clinical experience and the dearth of data on the use of Caloreen for newborn infants have prompted us to evaluate the effect of Caloreen on gastric emptying in the newborn period.

Caloreen is a white, slightly sweet powder prepared by the enzyme degradation of corn starch to give a mixture of malto-oligosaccharides containing $3 \%$ glucose, $7 \%$ maltose, $5 \%$ maltotriose, and $85 \%$ polysaccharides containing 4 to 15 glucose units (mean 5 units). ${ }^{6}$ After ingestion in adults Caloreen is readily converted to glucose by enzymatic action.?

\section{Methods}

An attempt was made to study gastric emptying in 18 infants in the first 6 weeks of life. All were patients

*Roussel Laboratories Ltd, Wembley Park, Middlesex, England. in the special care nursery because they were preterm or light-for-dates. Two preterm infants were excluded because of vomiting after the glucose test meal.

All infants were wholly or partially tube fed and each received a total of 4 test meals on 2 consecutive days, one of $10 \%$ Caloreen and one of $10 \%$ glucose on each day; the content of the first test meal was varied randomly and the meals were given in the reverse order on the second day. Tube-fed infants were given test meals over a period of 3 to 4 minutes. Those who could suck were given as much of the test meal as they could take by bottle; a study was considered unsatisfactory if the infant failed to consume the test meal within 5 minutes or regurgitated any portion of it. There is no agreement on the effect of posture on gastric emptying $;^{8-10}$ throughout our study all infants were nursed prone.

Gastric emptying was assessed using Husband and Husband's modification ${ }^{8}$ of the method described by Hunt and Spurrell. ${ }^{11}$ Phenol-red 0.24 $\mathrm{mg} / 100 \mathrm{ml}$ was added to the meals; this dye which is unabsorbed acts as a marker and has no effect on gastric emptying. ${ }^{12}$ Before feeding the infant's stomach was washed out with water so that it was free of large curds. Test meals were given at room temperature $3 \frac{1}{2}$ hours after the last routine feed in a volume of $14 \mathrm{ml} / \mathrm{kg}$ to infants in the first 4 days of life, and $21 \mathrm{ml} / \mathrm{kg}$ to those aged 5 days or more. After an interval of 30 minutes the gastric contents were aspirated and the stomach washed out with water to recover any remaining part of the feed. As phenol-red is a $\mathrm{pH}$ indicator, the $\mathrm{pH}$ was kept constant by mixing an equal volume of barbitone buffer ( $\mathrm{pH} \mathrm{8.7)} \mathrm{with} \mathrm{the} \mathrm{fluid} \mathrm{tested} \mathrm{before} \mathrm{measur-}$ ing its optical density by spectrophotometry at $548 \mathrm{~nm}$. By measuring the optical density of the original feed, the gastric aspirate, and the washout, it was possible to calculate the proportion of the original feed recovered, independently of added gastric secretion and saliva. ${ }^{8}$ 


\section{Results}

The percentage of gastric retention after Caloreen and glucose meals is presented in the Table and the Figure. Gastric emptying was faster after Caloreen than after glucose in all but one of the 32 studies. Gastric retention of more than $30 \%$ of the test feed at 30 minutes was seen after only $7(22 \%)$ of the Caloreen feeds compared with $25(78 \%)$ of the glucose feeds. Caloreen solution thus clearly left the stomach much more rapidly than the glucose solution.

Table Gastric emptying in 16 newborn infants after 2 test meals each of $10 \%$ Caloreen and 2 test meals each of $10 \%$ glucose solutions

\begin{tabular}{llllll}
\hline & $\begin{array}{l}\text { Gestation } \\
\text { at birth } \\
\text { (weeks) }\end{array}$ & $\begin{array}{l}\text { Birth } \\
\text { weight } \\
(\mathrm{g})\end{array}$ & $\begin{array}{l}\text { Age at } \\
\text { first study } \\
(\text { days })\end{array}$ & $\begin{array}{l}\text { Percentage of test } \\
\text { meal recovered from } \\
\text { stomach after } 30 \text { min }\end{array}$ \\
\cline { 5 - 6 } & & & & Caloreen & Glucose \\
\hline Range & $29-37$ & $1240-2690$ & $2-37$ & $5-69$ & $9-84$ \\
Mean & 33.8 & 1842 & 14 & 20 & 44 \\
SEM & 0.62 & 98 & 2.4 & 2.6 & 3.5 \\
\hline
\end{tabular}

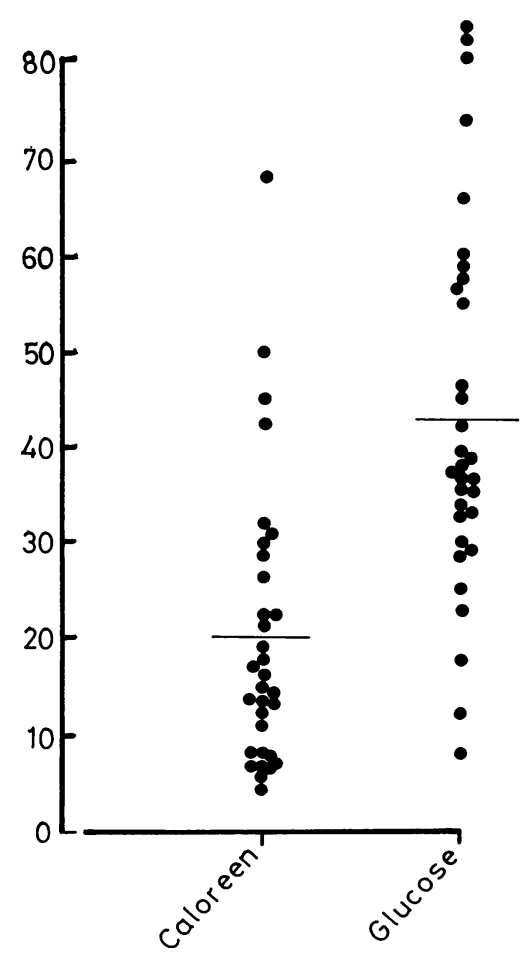

Figure Percentage of test meal recovered 30 minutes after meals of $10 \%$ glucose and $10 \%$ Caloreen solutions in water. The means for the solutions are shown.

\section{Discussion}

In adults the duodenum contains osmoreceptors; a high osmolality in the duodenal contents delays gastric emptying. ${ }^{12}$ Husband and Husband ${ }^{8}$ concluded that these osmoreceptors were functional within the first few days of life by demonstrating that a $10 \%$ glucose solution emptied from the stomach at a slower rate than a $5 \%$ glucose solution. It has also been shown that a starch solution emptied from the stomach of the newborn infant more rapidly than a glucose solution of comparable energy content, ${ }^{13}$ whereas in the adult Hunt and Pathak $^{14}$ found that starch and glucose solutions left the stomach at about the same rates. The postpyloric osmoreceptors apparently respond to starch only after conversion to maltose and glucose by pancreatic amylase and intestinal maltase, and Husband et al. ${ }^{\mathbf{1 3}}$ attributed the more rapid gastric emptying in the newborn after starch feeds to the relative deficiency of pancreatic amylase, previously demonstrated during the first few months of life by Andersen. ${ }^{15}$ Similar rapid emptying of starch meals has been demonstrated in patients with deficient pancreatic secretion. ${ }^{16}$ As Caloreen is also converted to glucose by amylases, this would explain the rapid emptying of Caloreen from the infant's stomach.

Glucose is widely used as a first feed and as an energy supplement in the neonatal period. Experience with Caloreen is limited but it has some theoretical advantages over glucose because of its lower osmotic activity (a $10 \%$ solution has an osmolality of $120 \mathrm{mosmol} / \mathrm{l}$ compared with $555 \mathrm{mosmol} / \mathrm{l}$ for a glucose solution of similar strength and energy content) and our results indicate that it leaves the stomach much more rapidly than glucose. Since the danger of regurgitation with subsequent aspiration into the lungs is a limiting factor in prescribing the volume of enteral feeds for low birthweight infants during the early days of life, there may be some advantage in using Caloreen rather than glucose or other simple sugars. However, if we are correct in our speculation that Caloreen empties rapidly from the stomach not only because of its low osmolality in solution but also because it is not digested in the newborn period, it is possible that it might not be absorbed; if this were so there would be no nutritional benefit in using it. However, tolerance tests comparing Caloreen with glucose show that Caloreen produces a sustained rise in the plasma glucose concentration. ${ }^{17}$ It is therefore concluded that Caloreen has significant advantages over glucose as a carbohydrate supplement in infant feeding.

We thank Dr G Hems for statistical help, Professor A G M Campbell for advice, and Miss Gordon, 
Pharmacy Department, Royal Aberdeen Children's Hospital, for assistance.

\section{References}

1 Crump E P, Gore P M, Horton C P. The sucking behavior in premature infants. Hum Biol 1958; 30: 128-41.

2 Gryboski J D, Thayer W R, Spiro H M. Esophageal motility in infants and children. Pediatrics 1963; 31: 382-95.

3 Wharton B A, Bower B D. Immediate or later feeding for premature babies? A controlled trial. Lancet 1965; ii: 969-72.

4 Smallpeice V, Davies P A. Immediate feeding of premature infants with undiluted breast milk. Lancet 1964; ii: $1349-52$.

5 Russell G, McKay E. Blood glucose concentration in the perinatal period. Arch Dis Child 1966; 41 : 496-502.

${ }^{6}$ Berlyne G M, Booth E M, Brewis R A L, Mallick N P, Simons $\mathbf{P}$ J. A soluble glucose polymer for use in renal failure and calorie-deprivation states. Lancet 1969; i: 689-92.

7 Ricketts C R. Glucose polymers in health and disease. In: Mallick N P, ed. The role of Caloreen. Lancaster: MTP Press, 1976: 3-12.

8 Husband J, Husband P. Gastric emptying of water and glucose solutions in the newborn. Lancet 1969; ii: 409-11.

9 Yu V Y H. Effect of body position on gastric emptying in the neonate. Arch Dis Child 1975; 50: 500-4.
10 Blumenthal I, Ebel A, Pildes R S. Effect of posture on the pattern of stomach emptying in the newborn. Pediatrics $1979 ; 63$ : 532-6.

11 Hunt J N, Spurrell W R. Pattern of emptying of human stomach. J Physiol (Lond) 1951; 113: 157-68.

12 Hunt J N. Some properties of an alimentary osmoreceptor mechanism. J Physiol (Lond) 1956; 132: 267-88.

13 Husband J, Husband P, Mallinson C N. Gastric emptying of starch meals in the newborn. Lancet 1970; ii: 290-2.

14 Hunt J N, Pathak J D. The osmotic effects of some simple molecules and ions on gastric emptying. J Physiol (Lond) 1960; 154: 254-69.

15 Andersen D H. Pancreatic enzymes in the duodenal juice in the celiac syndrome. Am J Dis Child 1942; 63: 643-58.

16 Mallinson C N. Effect of pancreatic insufficiency and intestinal lactase deficiency on the gastric emptying of starch and lactose (abstract). Gut 1968; 9: 737.

17 Russell G, Costalos C. Oral tolerance of Caloreen in babies. Arch Dis Child 1980; 55 : 886-7.

Correspondence to Dr G Russell, Department of Child Health, University Medical Buildings, Foresterhill, Aberdeen AB9 2ZD.

Received 16 October 1979

The following articles will appear in future issues of this journal:

Late presentation of vitamin D-dependent rickets. $J$ Cowen and $F$ Harris

Screening for congenital hypothyroidism. D B Grant and $J$ A Hulse

Vaccination against pneumococcal disease. H P Lambert

Acute haematogenous osteitis. $J R$ Anderson, $J$ D Orr, D A Maclean, and W G Scobie

Neonatal rickets. Histopathology and quantitative bone changes. S J Oppenheimer and G $J$ A I Snodgrass

Prostaglandins in human milk. A Lucas and M D Mitchell 